\title{
Ullrich Langer, Penser les formes du plaisir littéraire à la Renaissance
}

\section{Dario Cecchetti}

\section{Q OpenEdition}

12 Journals

\section{Édition électronique}

URL : http://journals.openedition.org/studifrancesi/6257

DOI : 10.4000/studifrancesi.6257

ISSN : 2421-5856

Éditeur

Rosenberg \& Sellier

\section{Édition imprimée}

Date de publication : 1 novembre 2010

Pagination : 545

ISSN : 0039-2944

\section{Référence électronique}

Dario Cecchetti, «Ullrich Langer, Penser les formes du plaisir littéraire à la Renaissance », Studi Francesi

[En ligne], 162 (LIV | III) | 2010, mis en ligne le 30 novembre 2015, consulté le 11 janvier 2021. URL: http://journals.openedition.org/studifrancesi/6257 ; DOI : https://doi.org/10.4000/studifrancesi.6257

Ce document a été généré automatiquement le 11 janvier 2021.

\section{(c) (i) (9)}

Studi Francesi è distribuita con Licenza Creative Commons Attribuzione - Non commerciale - Non opere derivate 4.0 Internazionale. 


\title{
Ullrich Langer, Penser les formes du plaisir littéraire à la Renaissance
}

\author{
Dario Cecchetti
}

\section{RÉFÉRENCE}

ULLRICH LANGER, Penser les formes du plaisir littéraire à la Renaissance, Éditions Classiques

Garnier, 2009 («Études et essais sur la Renaissance», 86), pp. 269.

1 «Cette étude ne se veut pas un registre des plaisirs, mais une réflexion sur le plaisir dans son rapport intime avec la littérature à la Renaissance. La littérature - sa lecture - fait partie des plaisirs, elle est un plaisir, mais elle a aussi cette caractéristique qu'elle partage avec les autres arts mimétiques, de représenter le plaisir dans ses multiple manifestations» (p. 9): così l'A. pone le premesse per la sua indagine in apertura di libro. In effetti, l'interessante saggio, ricostruendo la percezione e definizione di piacere nel Rinascimento e ponendosi l'interrogativo di come la cultura intellettuale del Cinquecento 'pensi' il piacere, al di fuori del discorso teologico, definisce le forme che il piacere può rivestire, a partire da una serie di definizioni che risalgono alla retorica e alla filosofia morale aristotelica ma che agiscono fino ai discorsi teorici rinascimentali. Avendo stabilito che queste forme di piacere sono tutte incarnate nel testo letterario e che certi generi di letteratura sembrano attirati da certe forme, più che da altre, U. Langer propone le seguenti connessioni tra forme di piacere e generi letterari. Il piacere-pl\%orúsis con la novella che privilegia l'ingannatore ingannato e l'ordine ristabilito; il piacere-kin\%osis con il romanzo, e con qualsiasi tipo di narrazione episodica che rappresenti un mondo di avvenimenti rapidi, imprevedibili; il piacereenergeia con qualsiasi tipo di letteratura fondata sulla nozione di una società civilizzata, capace di padroneggiarsi; il piacere-telos con il dramma, e con quelle forme di narrazione che gli somigliano e si fondano sul concatenarsi di una logica finalista. Un tipo, infine, di piacere non repertoriato dai filosofi classici, in quanto considerato poco degno, e che un certo tipo di lirismo rappresenta come quello che oltrepassa tutti gli 
altri, ovvero l'estasi della 'perdita' di se stesso. Il discorso si snoda attraverso alcuni autori fondamentali, quali Ronsard, Rabelais, Marguerite de Navarre, Montaigne. 